\title{
7 ETWEEN TRUTH AND MEMORY: IMAGES IN LITHUANIAN HISTORICAL DOCUMENTARIES IN POST-COMMUNIST TRANSFORMATION PERIOD
}

\section{Rūta Šermukšnytè}

Vilnius University, Faculty of History, E-mail: ruta.sermuksnyte@if.vu.lt

\begin{abstract}
:
The goal of this paper is to reveal how and why the circulation of the same historical images takes place; whose values and, simultaneously, memory are conveyed through these images; what is the relationship between the audiovisual representation of the past and collective memory? The article states that manifestations of the visual stereotypes of Lithuania history in post-communist transformation period (1988-2004) are mainly based on certain cinematic tendencies. Historical films that are considered to be an adaptation of the national narrative cinematography have been predominant since 1988. This kind of narration is characterized by validation of history as a national value, formation of national identity and its stabilization rather than diversification and correction of the collective memory or the development of critical thinking. The current documentary material that is based on the understanding of history as a myth of the nation's history is not aimed at creating a new visual and verbal narration about the realities of the past, but rather at recognizing what has been said and made in the previous works.
\end{abstract}

\section{Rezumat:}

Scopul acestei lucrări este de a releva cum și de ce are loc circulația acelorași imagini istorice; ce valori și totodată ce fel de memorie este transmisă prin aceste imagini; care este relația dintre reprezentarea audiovizuală a trecutului și memoria colectivă? Articolul afirmă că manifestările stereotipurilor vizuale ale istoriei Lituaniei in perioada postcomunistă de transformări (1988-2004) sunt bazate, $\hat{n}$ principal, pe câteva tendințe cinematografice. Filme istorice care sunt considerate a fi o adaptare a narațiunii cinematografiei naționale au fost predominante incepând din anul 1988. Acest tip de narațiune este caracterizată de o validare a istoriei ca valoare națională, formarea unei identități naționale și stabilizarea acesteia în locul diversificării și corectării memoriei colective sau dezvoltării gândirii critice. Materialul documentar actual, care este bazat pe înțelegerea istoriei ca un mit al istoriei naționale, nu are scopul de a crea o nouă narațiune vizuală și verbală despre realități ale trecutului, ci mai degrabă de a recunoaște ceea ce a fost deja afirmat și realizat în lucrări anterioare. 
Keywords: collective memory, Lithuanian historical documentary, image, postcommunist transformation period

\section{Introduction}

Among the most important cognitive problems faced by researchers into audiovisual culture during recent decades is the interaction between audiovisual creativity and history. Due to the double meaning of the word "history" -1) an event in the past and 2) the interpretation of that event - this problem is multifaceted. First of all, we are interested in audiovisual culture as a certain reflection of values of a society of a certain historical period, a means to affect the audience, an instrument of propaganda and similar questions. Secondly, we research into the possibilities of audiovisual means to interpret history, to create unique visions of the past following postmodern ideas. Thirdly, these two groups of questions intersect in the wide field of studies in historical culture or memory, the subject of which is still defined in a variety of terms: historical memory, collective memory, social memory, myth, and historical consciousness, etc. Memory named in one or another way is a mediated phenomenon, that is, its existence is inseparable from various media of memory "that help us construct and transmit our knowledge and feelings about the past rely on various combinations of discursive, visual and spatial elements". ${ }^{1}$

The question of relationship between audiovisual creation and the history is particularly relevant in researching the post-communist transformation period in Lithuania, which begins, according to Zenonas Norkus, the most famous Lithuanian researcher of post-communist transformation, with Mikhail Gorbachev's "perestroika", and ends in 2004, when Lithuania entered in European and transatlantic structures (accession to the European Union and NATO). ${ }^{2}$ During this process, several social directions are visible. First of all, it is the rebuilding direction characterized by the model of interwar Lithuania (1918-1940). Also, a direction imitating

\footnotetext{
1 Wulf Kansteiner, 'Finding Meaning in Memory: A Methodological Critique of Collective Memory Studies', History and Theory 41, 2 (2002): 190.

2 For more information, see Zenonas Norkus, On Baltic Slovenia and Adriatic Lithuania: A Qualitative Comparative Analysis of Patterns in Post-communist Transformation (Vilnius: Apostrofa, 2012); Zenonas Norkus, Kokia demokratija? Koks kapitalizmas?: pokomunistine transformacija Lietuvoje lyginamosios istorines sociologijos požiüriu [Which Democracy, Which Capitalism?: Postcommunist Transformation in Lithuania from the Viewpoint of Comparative Historical Sociology] (Vilnius: Vilniaus universiteto leidykla, 2008).
} 
Western realities can be discerned. The third direction continues the Soviet tradition. Finally, the innovative direction is visible which is characterized by a creation of new and yet unseen coexistence structures. ${ }^{3}$ We have several directions which, according to the analysis of Vasilijus Safronovas, the researcher of Lithuanian memory culture and politics, had influence on policy priorities and inspired various interpretations of Lithuanian history. The audiovisual culture in Lithuania is also not an exception, where (as in the whole region of Central and Eastern Europe) history is one of priority topics. The researchers note that since 1988 there appeared a lot of documentaries of chronicle, survey and "textbook" nature (mostly created on television or in cooperation with it) which filled the white places of cinema or were fixing the history of the Soviet model. ${ }^{5}$

The attention to the post-communist transformation problems, in turn, led to the selection of audiovisual creation chosen for investigation. According to Dina Iordanova, the researcher of Eastern and Central European cinema, since 1989, with the beginning of destructuration of the centralized cinematographic system and financial crisis, the documentaries became the most popular type of creation in the entire region of Central and Eastern Europe. Due to a high number of documentaries made - it became the main medium to record and distinctively reflect the transformation changes in postcommunist societies. ${ }^{6}$

In Lithuania, the role of the medium of collective memory was, and still is, attributed to Lithuanian historical documentaries, which since the beginning of democratisation (since the second phase of perestroika c. 1988) have mostly focused on the pre-war (1918-1940) and Soviet periods (19451990). The same historical images are used for the representation of these historical periods, which affects the visual stereotyping of history. The goal of this paper is to reveal how and why the circulation of the same historical images takes place; whose values and, simultaneously, memory are conveyed through these images; what is the relationship between the audiovisual representation of the past and collective memory? Thus, the subject of images

\footnotetext{
3 See more Norkus 2012, 49-94. Also see Marius Povilas Šaulauskas, 'Postkomunistinès revoliucijos želmenys: iš revoliucinio tarpsnio ị postmodernią Lietuvą?', Sociologija: Mintis ir veiksmas 1 (1998): 77-94.

4 Vasilijus Safronovas, 'Lietuvos atminimo politikos tendencijos po 1990 metú', in Alvydas Nikžentaitis (sud.), Nuo Basanavičiaus, Vytauto Didžiojo iki Molotovo ir Ribbentropo: atminties ir atminimo kultūru transformacijos XX-XXI amžiuje (Vilnius: Lietuvos istorijos instituto l-kla, 2011), 337-378.

5 See Genovaitė Burneikienè et al, Žurnalistikos enciklopedija (Vilnius: Pradai, 1997), 109.

${ }^{6}$ Iordanova, 32-33.
} 
88 | Revista Română de Studii Baltice și Nordice/The Romanian Journal for Baltic and Nordic Studies 7(2)

in Lithuanian historical documentaries should be treated as some kind of a "Gordian Knot" in which aforementioned cognitive tasks (visual representation of the past, audiovisual culture as a certain expression of values of a society and a medium of memory) intertwine.

\section{Historical Documentaries as a Historical Truth Telling Mode? \\ I. 1. Research into Historical Documentaries}

Documentaries that pretend to be a truth telling mode necessitate a specific method of the search for truth. ${ }^{7}$ It can be called documentary research, which is similar to research conducted by an academic historian. Since the explanation of the process of the past provided both by documentary filmmakers and academics is not contrived, and is non fictional, it has to be based on certain written, physical, visual and / or audio sources of historical information. According to the television editor Peter Latzel, an "ideal" documentary research covers such stages as: research of literature on the subject; interviews with experts (they help in the search of literature and historical sources as well as informers, they also aid in defining the topic); work in public and private archives; and questioning informers (including contemporaries). ${ }^{8}$ We think that these activities of a documentary film or program makers are as prevalent to a historian or historical researcher. Identifying similarities between activities of documentary film and program makers and historian it is necessary to emphasise their differences. P. Latzel names two of them: firstly, the research carried out by documentary film or program makers usually covers phenomena of a larger historical space-time; secondly, the limit of time restricts the research of documentary film or program makers. ${ }^{9}$ We would think that the essential difference lies not in the subject and the frame of work time, but in following the rules of empirical research, the most important of them being a critical attitude towards sources. Although P. Latzel declares that documentary film and program makers should verify sources, check the reliability of received information, we think that film and program makers who do not have specific instruments of

\footnotetext{
7 In this case the so-called deconstructionist documentaries related to the ideas and work of such directors as Jill Godmilow and Claude Lanzmann are left aside. For more see Paula Rabinowitz, 'Wreckage upon Wreckage: History, Documentary and The Ruins of Memory', History and Theory 32, 2 (1993): 119-137.

8 See Peter Latzel, 'Die Recherche für historische Sendungen', in Guido Knopp, Siegfried Quandt (Hg.), Geschichte im Fernsehen. Ein Handbuch (Darmstadt, 1988), 42-47. It is necessary to add that some stages of this research are discovered also while creating historical feature films; however, this is a theme for another paper.

${ }^{9}$ Latzel, 41.
} 
historical research to analyse sources in their disposition and have to rely on experts when they reach the stage of control. Another difference between the activities of documentary film and program makers and researchers lies on the level of discourses created by these two kinds of specialists. The power of written and audiovisual discourses of documentary and non-fictional origin lies in the fact that they not only refer to various sources of information, but also consist of them: they become the "building material" of the work, which is selected, reduced, edited until it acquires a certain form. The peculiarity of audio-visual history is that it is necessary to have acoustic and visual information for its construction. Lithuanian historical documentary filmmaker Rimtautas Šilinis said during one interview that he was envious of historians "who can "chop" a whole chapter of a book from one piece of paper. Cinema, unfortunately, cannot do that". ${ }^{10}$ In historical documentaries the "building material" can be divided into the following main groups: new shots related to the subject (witnesses of events, contemporaries or experts, also images of landscapes or objects related to the theme and fictional scenes); and historical cinematographic or still images, animation, sound records. A combination of these structural elements in documentaries has to convince the audience of the reliability of the interpretation of the past, hence, the historical accuracy of the documentary.

\section{2. Historical Images as a Part of the Historical Truth of the Film}

As aforementioned, among the most important "building materials" in documentaries is historical cinematographic footage. Using it (also documents, manuscripts, documentary photographs, historical maps, historical sound tracks, etc.) as authentic relics of the past is useful not only for the rendering of the "oldness", "the charm of difference"11, but also as the evidence of the historical truth of the film. However, what truth does the historical cinematographic footage produce? The American communication specialist John Fiske speaks of metonymy characteristic to cinematographic images, which is defined as a process where the whole is represented by its part. ${ }^{12}$ Recording / demonstration of a certain sequence of images is on its

10 Rimtautas Šilinis, Rasa Paukštytè, “"Ivvertinkite litais gyvo Maironio kadrus”. R. Paukštytès pokalbis su R. Šiliniu', Kinas, žiema (1999), 12.

11 See Hans Jürgen Pandel, 'Bild und Film. Einsätze zu einer Didaktik der 'Bildgeschichte", Geschichtsbewusstsein und Methoden historischen Lernens / Hg. B. Schönemann, U. Uffelmann, H. Voit (Weinheim: Deutsche Studien Verlag, 1998), 165. See also Hans Jürgen Pandel, 'Bildlichkeit und Geschichte', Geschichte lernen 5 (1988), 13.

12 John Fiske, Introduction to Communication Studies (London / New York: Routledge, 1996), 9596. 
90 | Revista Română de Studii Baltice și Nordice/The Romanian Journal for Baltic and Nordic Studies 7(2) own metonymical because the cinematographer / translator choose only one episode representing the whole from $n$ possible variations following certain considerations. According to communication specialists Vilija Gudonienè, Dieter Franck and J. Fiske, most often film and television cinematographers tried and try to record events that meet the criteria of "big headlines"; i.e. which are related to the institutions of power, dramas, the unusual, and dominating narratives. ${ }^{13}$

When making films a contemporary documentary filmmaker has to refer to the cinematographic heritage of a certain length. However, both in Lithuania and abroad, there is a tendency to select from a larger and smaller quantity of shots always the same images and use them. A "set of images" used most often in Lithuanian historical documentaries on the subject of the 20th century Lithuanian history can be identified. Let us list several of its components. Pre-war Polish Vilnius is most often represented by footage received from the Warsaw Documentary Film Studio Archive: the Władysław Belina's - Prażmowski's cavalry regiment entering through the Gates of Dawn in 1919; the Polish flag in the Gedimino Tower; Józef Pilsudski visiting Vilnius; a parade of Polish Army in Gedimino Alley. The event of returning Vilnius to Lithuania in 1939 is rendered through the shots from the film created the same year, Returning the Vilnius Region (Vilniaus krašto gražinimas), from which the most popular is the ceremony of cutting the barrier separating Lithuania and then Polish Vilnius region and scenes of the army marching to Vilnius. The annexation of Klaipèda region by Nazi Germany in 1939 is most often represented by footage from a documentary film created by Raimondas Vabalas in 1964, Only the Fuehrer is Missing (Stinga tik fiurerio). The film used chronicle footage received from German archives that recorded Hitler's journey to Klaipèda and moments of his visit; also footage from a meeting of neo-Nazis of the FRG. Having viewed films using Nazi footage, we can conclude that Lithuanian cinematographers are most fond of the episode when the Lithuanian inscription "Klaipeda Ticket Office" is coated with white paint leaving only the German words "Kartenverkauf- Fähre". The annexation of Lithuania by the USSR in 1940 is depicted cinematographically using footage of the delegation of Lithuanian Seimas (Parliament) travelling to Moscow on 30 July 1940 to ask the Supreme Soviet to allow Lithuania to join the USSR. The visual stereotyping of history is conditioned not only by

\footnotetext{
13 See first of all Vilija Gudonienè, 'Kodèl naujienos?', Semiotika: Šiuolaikinio socialinio diskurso analize 4 (1997), 21-25. Also see Dieter Franck, 'Die historische Dokumentation', Geschichte im Fernsehen, 49-50; Fiske, 96.
} 

repeating the same images, but also through the formation of a conventional iconography representing a certain period. Documentaries of the National revival Movement "Atgimimas" period (1988-1990) formed a conventional set of images of the Revival. It includes scenes from meetings in Vingis Park, exhumations, memorial and religious rituals. Paratroopers in the lobby of Lithuanian National Television on the night of January 12-13, 1991, the radio announcers Bernadeta Lukošiūtè and Algimantas Sadukas, the last words of Eglè Bučelytė on a television program, the address of Vytautas Landsbergis to the crowd gathered at the Parliament and common prayer, the "massacre" at the television tower and burial of the dead, barricades at the House of Seimas - a certain combination of these episodes represents the bloody events of January 1991. It would be relevant to ask why there is a tendency to choose and always use the same images from repositories both large and small.

\section{3. Habits of Using Historical Footage}

Circulation of the same historical footage related to a certain tradition of using images isn't exclusive to Lithuania. Several cases have been observed when after having purchased a copy of historical footage from Lithuanian or foreign image and sound archives, which are not cheap; it serves for several films or programs. There are also examples when a director uses film created at an earlier date. ${ }^{14}$ Of course it is possible to argue against the ideas presented above concerning "multiplication" of the same footage with a statement that Lithuanian film and television documentary film or program makers lack cinematographic material because we lost most of it during occupations. We would think that the problem lies not in the lack of visual heritage but in an unsatisfactory search for cinematographic sources. There is evidence that there is Lithuanian film footage in video archives of France, Germany, England, Denmark, Russia, USA and other countries as well as private archives. ${ }^{15}$ Yet from time to time we heard statements from Lithuanian film critics and

\footnotetext{
14 For example, in films A Flower on the Path (Gèle ant tako, directed by V. Damaševičius, LRT, 1993) and Legal Evil (Iteisintas blogis, directed by B. Morkevičius, LRT, 2001) images from A Northern Golgotha (Šiaurès Golgota, directed by R. Šliažas, LRT, 1991) have been used. The documentary filmmaker Edmundas Zubavičius used some of footage from the film Women Partisans (Partizanes, 1995) in another of his films, The Fullness of Loneliness (Vienatvès pilnatis, 1996).

15 See Skirmantas Valiulis, 'Kinas, istorija ir ideologiniai kontekstai', in Alfredas Bumblauskas, Nerijus Šepetys (sud.). Lietuvos sovietine istoriografija: teoriniai ir ideologiniai kontekstai (Vilnius: Aidai, 1999), 271. See also Regina Jackūnaitè, Ikikariné Lietuvos kino dokumentika: istorijos šaltinis ir jo panaudojimas kino ir televizijos dokumentiniuose filmuose. MA dissertation. Supervisor Prof. dr. A. Bumblauskas (Vilnius University, Faculty of History, Department of History Theory and History of Culture, 1999).
} 
filmmakers against "lazy" documentary filmmakers who rarely visit archives, read little, have little interest and do not understand the value of a fact and document. ${ }^{16}$ There are some signs that the reason for a closed circulation of images could lie also in a specific problem: a lack of understanding of a historical image as a document. As an example we could quote the film Two Occupations (Dvi okupacijos, directed by A. Digimas, LKS, 1995). From the visual point of view there is nothing wrong with this film: the German occupation in 1941-1944 is represented by footage that recorded the German occupation in Lithuania. Yet the film's voice-over commentary is surprising. When showing men in the Reich labour service standing in formation and holding spades, it states that Germans treated Lithuanians as thick-headed and stupid; apparently the process of explaining the construction of spades and other equipment recorded in the footage is evidence to this. A detailed analysis of this footage recorded around 1943-1944 shows that it was really not made to humiliate Lithuanians. ${ }^{17}$ In the third part of footage which was used for the film Two Occupations we see Lithuanians in forced labour service for the Reich and their main attributes are German military uniform and spades. The footage has recorded how they exercise with spades; listen to a sergeant's lecture acquainting them with their work equipment. The fragment of footage ends with an address to representatives of the Lithuanian nation in which men born in 1926 are encouraged to take example from young people of Lithuania recorded in footage to join the Reich labour service. Thus, this footage is one among many promoting the activities of this service, but not humiliating Lithuanians, preserved in the Division of Sound and Image. This example shows how history is visually falsified when certain shots cleaving to contemporary perceptions are covered with a commentary distorting the meaning of these shots.

On the evidence, some Lithuanian cinematographers still understand images as an illustration and not as a visual source of history recording a specific fact and its uniqueness. According to Arseny Gulyga, works using footage as a visual "envelope" are akin to pseudo-histories, which only create an illusion of research into the past, and really it (the past) remains even more hidden under a thick verbal or visual curtain. ${ }^{18}$ To tell the truth, not all specialists of historical cinematography dislike manipulation of historical

\footnotetext{
16 See Rasa Paukštytè, 'Ne tik apie vieną “Epitafiją"', Kinas, žiema, (1998-1999), 24-25. See also Šilinis and Paukštytè, 8-13.

17 See Lietuvos centrinio valstybès archyvo Vaizdo ir garso dokumenty skyrius [The division of Sound and Image of Lithuanian Central State Archive], S. v. nr. 991.

18 Арсении Гулыга, Эстетика истории (Москва: Наука, 1974), 123.
} 

images. Marita Sturken does not believe statements that historical footage is an unalterable medium of the past, a keeper of original meanings. According to her, precisely an arbitrary combination of historical shots shows that memories are continuously rescripted, reenacted and retold. ${ }^{19}$ This statement by Sturken points to the fact that we have to look for reasons for the visual stereotyping of 20th century Lithuanian history in the nature of historical documentaries as a medium of memory.

\section{Historical Documentary as a Medium of Memory II. 1. Historical Images in Subordination of the National Myth of History}

In order to understand historical documentaries as participants in the process of creating and developing collective memory it is necessary to take into account its simultaneous interaction with other factors: with intellectual and cultural traditions, which frame representations of the past, and with memory consumers who use, transform or ignore representations of memory. Collective memory lends unity to a collective, a proof of originality and guidelines for its activities are a result of interaction among these three participants. ${ }^{20}$ One tradition used by memory makers is the "great" national narrative constructed by nationalist ideologists (the nationalist narrative) which answers questions fundamental to the nation: where are we from? Where are we and whereto are we going? The conception of the national myth of history is closely linked with the notion of a national narrative. The semiotician Algirdas Julius Greimas typified ideology and mythology in two ways, in which models through which people give manifest meaning to their lives: "One of them is a conceptualised way expressed in abstract words, academic terminology or political ideology; the other is the mythmaking way of manifestation, the existence of the same ideological truths and lies with the help of poetry, religion, art and all other inscribed or hidden values". ${ }^{21}$ Next to the aforementioned figurative explanation of myth by A. J. Greimas, the sociologist Irena Šutiniene supplements the definition of the national myth of history with a functional meaning suggested by Anthony Smith. According to I. Šutiniene, it is ideological functions of the nationalist narrative (a link with the past, orientation and mobilisation) that make this narrative into the

\footnotetext{
19 See Marita Sturken, 'Reenactment, Fantasy, and the Paranoia of History: Oliver Stone's Docudramas', History and Theory 36, 4 (1997): 76.

20 See Kansteiner, 180. See also Alon Confino, 'Collective Memory and Cultural History: Problems of Method,' The American Historical Review 102, 5 (1997): 1391.

21 Algis Julius Greimas, 'Mitai ir ideologijos', Metmenys 12 (1966), 14.
} 
national myth of history. In order to match these functions myths are presented in such effective forms as symbols, rituals and monuments. ${ }^{22}$ Thus, a necessary condition of collective memory is the establishment and effectiveness of a certain explanation of the past in the world lived by members of a certain collective. ${ }^{23}$ Researchers of mass communication have revealed in their research the metonymic nature not only of visual material but also of myth. According to J. Fiske, "one sign [...] stimulates us to construct the rest of the chain of concepts that constitute a myth, just a metonym stimulates us to construct the whole of which it is a part". ${ }^{24}$ In Lithuanian documentary film and program making the subject of 20th century history lies in certain images that serve as references to phenomena, events and processes of the past that functioned in the collective memory of Lithuanian society at the beginning of the renovated statehood (1991-1996): the pre-history of the loss of Lithuanian statehood (1918-1940); World War II and its occupations, deportations (1940-1941 and 1944-1953), resistance, sovietisation, and Revival, etc. ${ }^{25}$ For instance, photographs of executed partisans quoted abundantly are used as a metonym of post-war partisan struggle; the montage of rails, carriages and crosses is used as a metonym of war and post-war deportations, and images with Stalin and / or Ribbentrop and Molotov are a metonym of Russian and / or German politics with regard to Lithuania.

A circulation of the same images expressing certain conventional meanings is necessary for an image to become a visual reference to a myth. We think that the first documentary films "establishing" meanings of certain images have a special role to play here. They reduce the complex meaning of visual material by using certain montages or oral commentary. However, when the same images go from one film to another, directors no longer need

\footnotetext{
22 Irena Šutinienè, 'Tautos istorijos mitai Lietuvos gyventojų sąmonèje', in Arūnas Poviliūnas (sud.), Istorine samone ir istorijos didaktika (Vilnius: Solertija, 1997), 66.

${ }^{23}$ When this condition is absent (or is unknown) we have to speak of memories of the memory makers influenced by traditions and functioning in an elite and/or official environment. $\mathrm{W}$. Kansteiner presumes that representations of the past first of all show memories of its makers and not of the audience. The research into the total of representations of the past show the aggregate of individual memories, referred to by the English phrase 'collected memory', but not about the collective memory. See Kansteiner, 192 and186.

24 Fiske, 96.

25 The following sociological research shows the viability of these segments of the past in collective memory, see Vladas Gaidys, Danutè Tureikytè, Irena Šutininè, 'Istorinè lietuvių atmintis (empirinès charakteristikos)', Filosofija. Sociologija 1, 4 (1991): 77-87; Šutinienè 1997, 6689; Irena Šutininè, 'Istorinè Paribio gyventoju sąmonè ir jų integracija Lietuvos valstybejje', in Romualdas Grigas et al. (sud.), Paribio Lietuva: sociologine Paribio gyventoju integravimosi i Lietuvos valstybe apybraiža (Vilnius: Lietuvos Filosofijos ir Sociologijos institutas, 1996): 33-60.
} 
these means guaranteeing "appropriate" decoding because previous films "impose" the meaning of repetitive images onto later films. In terms of semiotics, such images become redundant; they don't inform (they lose the information due to constant circulation); they confirm already existing meanings, a link between members of a community (it is thought that we are united by the same understanding of history). ${ }^{26}$ A. Gulyga points out that constant repetition of images from historical footage causes "emotional inflation" of these documents: facts recorded visually lose their concreteness, uniqueness and turn into signs that express abstractions. ${ }^{27}$ Therefore, shots that are marked by conventional meanings reproduce the same visual version of history. This allows some researchers to claim that stereotypical shots form a specific visual collective memory. According to the German film historian Anton Kaes, "multiplication" of the same shots is a reason why precisely these images stick in the audience's minds as "correct" visual representations of a certain period. ${ }^{28}$ The didactic representative of German history Hans-Jürgen Pandel considers a canon of certain images immanent to every culture and uses a notion of collective memory of images (kollektives Bildgedächtnis) to name it. "It is possible to imagine this memory of images as a sum of mental visual representations that make our inner visual perception of personalities, places, events and epochs". ${ }^{29}$ According to H. J. Pandel, this specific memory, which guarantees the continuity of tradition, is not static, but changes depending on new needs for orientation.

\section{II.2. Lithuanian Documentary Film and Program Makers in the Con- struction and Evolution of Collective Memory}

We have to look for the beginnings of the visual stereotyping of the 20th century history of Lithuania in the year 1988. At that time, Lithuanian documentary film and program makers (like other representatives of revolutionary intellectuals and the political elite) took up the restitutory (or reconstructive) direction of historical politics, which manifested as a revival of the national narrative of history established during the interwar

period. This presupposed a certain collection of qualities of Lithuanian historical documentaries. Firstly, this production of cinema and television is

\footnotetext{
26 See Fiske, 16. See also Юрий Лотман, Семиотика кино и проблемы киноэстетики (Таллин: Ээсти Раамат, 1973), 19-20.

27 Sеe Гулыга, 123.

28 Anton Kaes, Deutschlandbilder. Die Wiederkehr der Geschichte als Film (München: Edition text+kritik, 1987), 90.

29 Pandel 1991, 63.
} 

oriented, in terms of theme, to one or several turning point events related to statehood (the origins of the nation, formation of statehood, strengthening, weakening, and loss, political and cultural efforts to get it back). Secondly, an ethnocentric (Lithuanian nation was perceived in terms of its ethnic identity) and monocentric (Lithuania is seen as the central subject of history) approach to the past of Lithuania. Thirdly, this creative work was an attempt to achieve ideological goals of mobilising and directing the nation. However, the process of creating and conveying national mythology that started during the Revival period and started gaining momentum did not fade. Films of this kind undergoing certain transformations and often commissioned by state institutions and public organisations and / or, according to the Lithuanian film critic Živilè Pipinytè, "synchronized" with the red dates on the calendar ${ }^{30}$, are still seen today. This causes a certain cliché character of audiovisual works: year after year the field of subjects in documentary films is filled with more or less known national heroes, victims, sufferings, elements of ethnic idiosyncrasy, the golden age of the nation and other elements of myths whereby a new knowledge of the past is neither created nor presented.

There is no necessity for films and television programs on historical subjects made for ideological purposes to see images as unique sources of history because history is used to confirm links in the community related by common origin, but not to create a new visual and verbal narrative about the past, it stabilises and doesn't alterthe collective memory. With such tendencies we can find one or two films in which historical images would be given significance as a phenomenon. Exceptions are found only in cases when the visual material used in films reflects another mythology. More examples of such deconstruction we will find in Lithuanian documentaries that use Soviet footage. Then they use the tradition of ideological montage: the text reveals the "falsity" of the Soviet footage and the visual material becomes a kind of anti-illustration. According to the critic of Lithuanian audiovisual culture Skirmantas Valiulis, the replacement of one cliché by another is the simplest action proving the shallowness of film script writers' fantasy. He claims that "if we want to confront those who are for re-sovietisation, we need also a better understanding of historical and film footage and a space for new ideas". 31

However the research into memory by Alon Confino, Jay Winter, Wulf Kansteiner and Hue-Tam Ho Tai enables the claim that the participation

30 See Živilè Pipinytė, 'Po tvano', Kinas žiema (1998-1999), 6.

31 Valiulis, 266. 
of historical documentaries in creating the collective memory of changing and non-monolithic Lithuanian society does not have to be understood in a simplified way - as its transparent expression or a direct factor. ${ }^{32}$ On the one hand, documentary filmmakers are independent and selective in application of traditions. This presupposes also such Lithuanian documentaries that correct the versions of national myths of history reaching the pre-war period reject or even create new myths. On the other hand, a heterogeneous audience is also an active preceptor, interpreter and refuter of representations of the past. Empirical research conducted in Lithuania points to a potential spectrum of decoding realised by the audience of historical documentaries, which reveals a variety of interpretations of elements from the same national myths of history and its changes ${ }^{33}$. Therefore, to find out which explanations of the past suggested by documentaries made for ideological purposes still function in the life - and collective memory - of the heterogeneous and developing Lithuanian society, it is necessary to analyse not only the habits of documentary coding processes, but also the decoding of documentary films by the audience. The latter aspect of audio-visual culture still awaits the attention of Lithuanian researchers.

\section{Conclusions}

1. The manifestations of stereotypes of visual Lithuanian history in the post-communist transformation period are mainly due to certain cinematic tendencies. Historical films that are considered to be an adaptation of the national narrative cinematography have been predominant since 1988. This kind of narration is characterized by validation of history as a national value, formation of national identity and its stabilization rather than diversification and correction of the collective memory or the development of critical thinking.

2. The current documentary material that is based on the understanding of history as a myth of the nation's history is not aimed at creating a new visual and verbal narration about the realities of the past, but rather at recognizing what has been said and made in the previous

\footnotetext{
32 See more Confino, 857-864; Jay Winter, 'Film and the Matrix of Memory', The American Historical Review 106, 3 (2001), 857-864; Kansteiner, 179-197; Hue-Tam Ho Tai, 'Remembered Realms: Pierre Nora and French National Memory', The American Historical Review 106, 3 (2001), 917-920.

33 See Irena Šutinienè, 'Lietuvos Didžiosios Kunigaikštystės paveldo reikšmės populiariosiose tautinio naratyvo interpretacijose', Lietuvos istorijos studijos 21 (2008), 102-120; Irena Šutinienè, 'Tautos istorijos simboliai Lietuvos gyventoju tautinèje vaizduotèje: heroju ịvaizdžiai ir jų kaita', Sociologija: Mintis ir veiksmas 1 (24) (2009), 40-62.
} 
works. Constantly circulating images in such creation can be defined not as much as documents - visually illustrating specific events, phenomena and processes, but more like signs - references to past interpretations already functioning in popular imagination. On the other hand, certain changes are visible in the chosen post-communist transformation period. Another type of documentaries appears which corrects and rejects the versions of nation's history myths, or creates new myths. New visual material is needed to achieve this.

3. The repetition of the visions is also related to visual material as illustration rather than a perception of it as a historical source of a certain fact. Due to such thinking of creators of documentary films, they are not very ardent in seeking for new material for films in foreign archives of view and sound. Sometimes a real meaning of views is being hidden under an additional comment behind the picture.

4. In the analyzed period, there are tendencies to represent (with the help of the same cinematic images or their different combinations) these ground-breaking historical events and processes of Lithuanian statehood in the 20th century: namely, the occupation of Vilnius and Klaipeda, the restitution of Vilnius, the annexation of Lithuania by the Soviet Union, collectivization, the National revival Movement "Atgimimas", and finally, the events of January 13 th. 1991. 


\section{References:}

\section{A. Archives:}

Lietuvos centrinio valstybes archyvo Vaizdo ir garso dokumentu skyrius [The division of Sound and Image of Lithuanian Central State Archive], S. v. nr. 991.

\section{B. Books and articles:}

Burneikienė, Genovaitė et al (sud.). Žurnalistikos enciklopedija. Vilnius: Pradai, 1997.

Confino, Alon. 'Collective Memory and Cultural History: Problems of Method', The American Historical Review 102, 5 (1997): 1386-1403.

Fiske, John. Introduction to Communication Studies. London / New York: Routledge, 1996.

Franck, Dieter. 'Die historische Dokumentation', in Knopp, Guido; Quandt, Siegfried (Hg.). Geschichte im Fernsehen. Ein Handbuch. Darmstadt, 1988: 49-53.

Gaidys, Vladas; Tureikytė, Danutė; Šutininė,Irena. 'Istorinè lietuvių atmintis (empirinès charakteristikos)' , Filosofija. Sociologija 1, 4 (1991): 77-87.

Greimas, Algis Julius. 'Mitai ir ideologijos', Metmenys 12 (1966): 9-27.

Gudonienè, Vilija. 'Kodèl naujienos?', Semiotika. Šiuolaikinio socialinio diskurso analize 4 (1997): 19-25.

Hue-Tam Ho, Tai. 'Remembered Realms: Pierre Nora and French National Memory', The American Historical Review 106, 3 (2001): 906-922.

Iordanova, Dina. Cinema of the Other Europe: The Industry and Artistry of East Central Europe Film. London: Wallflower, 2003.

Jackūnaitè, Regina. Ikikarine Lietuvos kino dokumentika: istorijos šaltinis ir jo panaudojimas kino ir televizijos dokumentiniuose filmuose. MA dissertation. Supervisor Prof. Dr. A. Bumblauskas. Vilnius University, Faculty of History, Department of History Theory and History of Culture, 1999.

Kaes, Anton. Deutschlandbilder. Die Wiederkehr der Geschichte als Film. München: Edition text+kritik, 1987.

Kansteiner, Wulf. 'Finding Meaning in Memory: A Methodological Critique of Collective Memory Studies', History and Theory 41, 2 (2002): 179-197.

Latzel, Peter. 'Die Recherche für historische Sendungen', in Knopp, Guido; Quandt, Siegfried (Hg.). Geschichte im Fernsehen. Ein Handbuch. Darmstadt, 1988: 41-48.

Norkus, Zenonas. Kokia demokratija? Koks kapitalizmas?: pokomunistine transformacija Lietuvoje lyginamosios istorinès sociologijos požiūriu [Which 
100 | Revista Română de Studii Baltice și Nordice/The Romanian Journal for Baltic and Nordic Studies 7(2)

Democracy, Which Capitalism?: Post-communist Transformation in

Lithuania from the Viewpoint of Comparative Historical Sociology]. Vilnius: Vilniaus universiteto leidykla, 2008.

Norkus, Zenonas. On Baltic Slovenia and Adriatic Lithuania: A Qualitative Comparative Analysis of Patterns in Post-communist Transformation. Vilnius: Apostrofa, 2012.

Pandel, Hans Jürgen. 'Bild und Film. Einsätze zu einer Didaktik der 'Bildgeschichte"', in Schönemann, Bernd; Uffelmann, Uwe; Voit, Hartmut (Hrsg). Geschichtsbewusstsein und Methoden historischen Lernens. Weinheim, 1998: 157-168.

Pandel, Hans Jürgen. 'Bildlichkeit und Geschichte', Geschichte lernen 5 (1988): 10-17.

Paukštytè, Rasa. 'Ne tik apie vieną “Epitafiją"', Kinas, žiema (1998-1999): 2425.

Pipinytè, Živilè. 'Po tvano', Kinas, žiema, (1998-1999): 6-8.

Rabinowitz, Paula. 'Wreckage upon Wreckage: History, Documentary and The Ruins of Memory', History and Theory 32, 2 (1993): 119-137.

Safronovas, Vasilijus. 'Lietuvos atminimo politikos tendencijos po 1990 metú', in Nikžentaitis, Alvydas (sud.). Nuo Basanavičiaus, Vytauto Didžiojo iki Molotovo ir Ribbentropo: atminties ir atminimo kultūru transformacijos XXXXI amžiuje. Vilnius: Lietuvos istorijos instituto 1-kla, 2011: 337-378.

Sturken, Marita. 'Reenactment, Fantasy, and the Paranoia of History: Oliver Stone's Docudramas', History and Theory 36, 4 (1997): 64-79.

Šaulauskas, Marius P. ‘Postkomunistinès revoliucijos želmenys: iš revoliucinio tarpsnio ì postmodernią Lietuvą?', Sociologija: Mintis ir veiksmas 1 (1998): 77-94.

Šilinis, Rimtautas; Paukštytė, Rasa. “Ǐvertinkite litais gyvo Maironio kadrus”. R. Paukštytès pokalbis su R Šiliniu', Kinas, žiema (1999): 8-13.

Šutinienè, Irena. 'Istorinè Paribio gyventoju sąmonè ir ju integracija Lietuvos valstybeje', in Romualdas Grigas et al. (sud.). Paribio Lietuva: sociologine Paribio gyventoju integravimosi i Lietuvos valstybe apybraiža. Vilnius: Lietuvos Filosofijos ir Sociologijos institutas, 1996: 33-60.

Šutinienè, Irena. 'Lietuvos Didžiosios Kunigaikštystès paveldo reikšmès populiariosiose tautinio naratyvo interpretacijose', Lietuvos istorijos studijos 21 (2008): 102-120.

Šutinienè, Irena. 'Tautos istorijos mitai Lietuvos gyventojų sąmonèje', in Poviliūnas, Arūnas (sud.). Istorine sąmone ir istorijos didaktika. Vilnius: Solertija, 1997: 66-89. 
Šutinienè, Irena. 'Tautos istorijos simboliai Lietuvos gyventojų tautinèje vaizduotejje: herojų ịvaizdžiai ir jų kaita', Sociologija: Mintis ir veiksmas 1 (24), (2009): 40-62.

Taylor, Richard (Ed.). The BFI Companion to Eastern European and Russian Cinema. London: British Film Institute, 2000.

Valiulis, Skirmantas. 'Kinas, istorija ir ideologiniai kontekstai', in Bumblauskas, Alfredas; Šepetys, Nerijus (sud.). Lietuvos sovietine istoriografija: teoriniai ir ideologiniai kontekstai (Vilnius: Aidai, 1999): 255271.

Winter, Jay. 'Film and the Matrix of Memory', The American Historical Review 106, 3 (2001): 857-864.

Гулыга, Арсений. Эстетика истории. Москва: Наука, 1974.

Лотман, Юрий. Семиотика кино и проблемы киноэстетики. Таллин: Ээсти Раамат, 1973. 